\title{
Recruitment in Nassau grouper Epinephelus striatus: post-settlement abundance, microhabitat features, and ontogenetic habitat shifts
}

\author{
David B. Eggleston* \\ North Carolina State University, Department of Marine, Earth and Atmospheric Sciences, \\ Box 8208 Raleigh, North Carolina 27695-8208, USA**, and \\ Caribbean Marine Research Center, Lee Stocking Island, Exuma Cays, Bahamas
}

\begin{abstract}
Nassau grouper Epinephelus striatus are of considerable ecological and commercial importance throughout the Caribbean, Gulf of Mexico and South Atlantic Bight, yet little is known of their settlement habitat and ontogenetic changes in early juvenile habitat requirements. Suction sampling in macroalgae, seagrass, and coarse calcareous sand habitats and visual surveys of artificial patch reefs were conducted systematically in 1991 to 1994 during wintertime onshore movement of late larval-early juvenile Nassau grouper within the vicinity of Lee Stocking Island, Bahamas. Recently settled fish $[\bar{x}=32 \mathrm{~mm}$ total length (TL)] resided within coral clumps (Porites spp.) covered by masses of macroalgae (primarily Laurencia spp.), with highest densities at $8 \mathrm{fish}^{-2}$ There was a positive and significant linear relationship between percent algal cover and post-settlement grouper density. Other habitat features such as algal displacement volume, and the numbers of holes, ledges, and sponges did not explain any significant variation in post-settlement density. Visual transects performed 4 to 5 mo after the settlement period (June) indicated that early juveniles ( $\bar{x}=85 \mathrm{~mm}$ TL) residing within or adjacent to algal-covered coral clumps were mostly solitary (88\%). Growth rates during February to June averaged $10 \mathrm{~mm} \mathrm{mo}^{-1}$ in 1993 . When densities of early juveniles were relatively high in 1991 and 1993 $\left(\bar{x}=0.03\right.$ fish $\left.\mathrm{m}^{-2}\right)$, there was also a positive and significant linear relationship between percent algal cover and early juvenile density. During 3 separate annual sampling periods, a decrease in early juvenile densities in macroalgal habitats from June to October was matched by a concomitant increase in abundance in artificial patch reefs located seaward of the macroalgal habitat. These habitat-specific abundance patterns suggest that juvenile Nassau grouper exhibit an ontogenetic habitat shift from macroalgal-Porites spp. clumps to patch-reef habitats at a size of 120 to $150 \mathrm{~mm}$ TL during late summer and early fall. Based on habitat associations observed in this study, E. striatus were classified into 3 stages: (1) post-settlement fish ( 25 to $35 \mathrm{~mm}$ TL) residing exclusively within algal-covered coral clumps; (2) early juveniles ( 60 to $150 \mathrm{~mm} \mathrm{TL}$ ) residing outside of and adjacent to algal-covered coral clumps; and (3) larger juveniles (>150 $\mathrm{mm}$ TL), which were generally associated with natural and artificial patch reefs.
\end{abstract}

KEY WORDS: Artificial reefs - Epinephelus striatus - Functional response model - Habitat complexity Laurencia spp. · Nassau grouper - Microhabitat · Ontogenetic habitat shift $\cdot$ Recruitment

\section{INTRODUCTION}

A common goal of marine ecologists is an understanding of the linkages between population variation and variability in the physical (i.e. oceanographic and

\footnotetext{
•E-mail: eggleston@meavax.nrrc.ncsu.edu

$\because$ Address for correspondence
}

meteorological) and biological environment (i.e. food and habitat availability, predation) over the various phases in the life cycle (Gaines \& Roughgarden 1985, Underwood \& Fairweather 1989, Bertness et al. 1992, Eggleston \& Armstrong 1995). Such integration is particularly important in many reef fishes, which release pelagic larvae that spend weeks to months in the water column, dispersing great distances and subsequently 
settling in spatially separated habitats (see reviews in Leis 1991, Victor 1991).

Settlement patterns of demersal fish are the consequence of biological and physical processes operating on the larval stages during the transition from a pelagic to a benthic existence. The intensity of local settlement is determined by the number of larvae that reach a location and settle. Larval supply can be influenced by current patterns (Kingsford \& Choat 1986, Kingsford et al. 1991), whereas settlement of strongly swimming larvae can be influenced by substrate selection behavior (Marliave 1977, Sweatman 1985, 1988). Subsequent post-settlement movements and mortality can also affect the distribution of demersal fishes and mask initial settlement patterns (Robertson et al. 1988, see reviews by Hixon 1991, Jones 1991).

Tropical and subtropical seagrass and mangrove habitats serve as important settling and nursery areas for numerous reef fishes (Weinstein \& Heck 1979, Stoner 1983, Sogard et al. 1989, Morton 1990). These habitats presumably intercept large numbers of larvae and provide abundant food resources and protection from predators (Parrish 1989). Fish eventually migrate from these nursery habitats to nearshore patch reefs and offshore reef habitats as they mature. Macroalgal species composition and spatio-temporal variation in macroalgal structural complexity (e.g. algal height, percent cover, stipe density) are two of the more important determinants of reef fish recruitment in temperate systems (Carr 1989, 1994, Levin 1991, 1993). Similar information with which to gauge the relative importance of macroalgal-rubble microhabitats as settlement and nursery areas for reef fish in subtropical and tropical systems is limited.

Commonly there is a positive relationship between between macrophyte structural complexity (e.g. density, biomass) and fish density in macroalgal and seagrass systems (e.g. Stoner 1983, Orth et al. 1984, Holbrook et al. 1990, Levin 1991, Carr 1994). The most common statistical approach used in identifying these relationships is to simultaneously examine a suite of habitat characteristics with stepwise, multiple regression models. The relationship between significant habitat characteristics and fish density is then assessed with linear (Stoner 1983, Holbrook et al. 1990, Levin 1991) and non-linear regression models (e.g. Carr 1994). Although Carr's (1994) statistical approach was rigorous in differentiating linear versus asymptotic relationships between habitat structural complexity and fish density, an objective criterion is also required for further identifying the statistical form of this relationship (i.e. linear, hyperbolic, sigmoid). Proper identification of the form of the relationship between habitat complexity and fish density is critical to identifying the ecological significance of habitat dynamics to fish distribution and abundance patterns (e.g Carr 1994). For example, a hyperbolic relationship indicates that fish density will increase at a much faster rate with small increases in habitat complexity than with ejther a linear or sigmoid relationship. A sigmoid relationship indicates that there is some habitat complexity threshold, above which fish density increases rapidly. Thus, fishes exhibiting either hyperbolic or sigmoid responses may be more sensitive to natural or anthropogenic changes in habitat complexity than species that respond in a linear fashion. The objectives of this paper are to describe early-life-history requirements of an ecologically and commercially important reef fish, the Nassau grouper Epinephelus striatus, by: (1) identifying the relative importance of seagrass, sand and macroalgal-coral complexes as settlement habitats; (2) documenting habitat associations and ontogenetic habitat shifts in early juveniles (<150 mm total length, TL); and (3) measuring spatio-temporal variation in benthic recruitment patterns and habitat use. A fourth objective was to provide statistical criteria and modelfitting approaches that can be used to identify the functional relationship (i.e. linear, hyperbolic, sigmoid) between habitat structural complexity and fish density.

The Nassau grouper is a tropical Western Atlantic serranid reaching $20 \mathrm{~kg}$ in weight and is one of the most important commercial finfish in the Caribbean, Gulf of Mexico and South Atlantic Bight (Jory \& Iversen 1989, Colin 1992). Adult Nassau grouper are widely dispersed along offshore coral reefs during most of the year but form large (500 individuals) spawning aggregations at specific sites during winter (Smith 1972, Colin 1992). Aggregations typically form near the full moon in December and January and have been severely overexploited (Bannerot et al. 1987 Russ 1991, Colin 1992). During spawning, gametes are released in discrete patches in the evening; planktonic larval duration is ca 30 to $45 \mathrm{~d}$ (Colin 1992). Although Epinephelus striatus populations are dependent on settlement of pelagic larvae to coastal locations, the benthic habitats to which they recruit and where they spend their early life remains undocumented (but see Beets \& Hixon in press)

\section{METHODS}

Field sites. Habitat surveys for Epinephelus striatus (summarized in Table 1) were conducted in the Exuma Cays, Bahamas, within the vicinity of Lee Stocking Island (LSI; $23^{\circ} 45^{\prime} \mathrm{N}, 76^{\circ} 10^{\prime} \mathrm{W}$; Fig. 1) during 1991 to 1994. Two adjacent locations of contrasting habitat type were initially chosen at the northern tip of Great Exuma to compare habitat associations of post-settlement and early juvenile Nassau grouper. The first loca- 
Table 1. Summary of survey methods, dates and habitats (sites; Fig. 1) sampled for post-settlement $(\bar{x}=31.7 \mathrm{~mm}$ total length, TL) and early juvenile ( $\bar{x}=85 \mathrm{~mm}$ TL) Nassau grouper Epinephelus striatus near Lee Stocking Island, Bahamas. Macroalgal sites in Barraterre Bay denoted by B1, B2, B3, and B4. First and second seagrass sites in Sugar Cay Bay and Shark Rock denoted by SC1 and SC2, and SR1 and SR2, respectively

\begin{tabular}{|c|c|c|c|c|}
\hline \multirow{2}{*}{$\begin{array}{r}\text { Habitat } \\
\text { Sites }\end{array}$} & \multirow{2}{*}{ Survey method } & \multirow[t]{2}{*}{ Date sampled } & \multicolumn{2}{|c|}{ Stage sampled } \\
\hline & & & Post-settlement & Early juvenile \\
\hline Macroalgae & Visual band transects & & & \\
\hline B1 & & Jun \& Oct 1991-93 & & $\mathrm{x}$ \\
\hline $\mathrm{B} 2$ & & Jun $1992-93$ & & $\mathrm{X}$ \\
\hline Seagrass & Visual band transects & & & \\
\hline $\mathrm{SC} 1, \mathrm{SC} 2$ & & Jun 1992-93 & & $\mathrm{X}$ \\
\hline Casitas & Stationary visual census & & & \\
\hline $\mathrm{SC} 1, \mathrm{SC} 2$ & & Jan-Mar 1991-93 & $\mathrm{x}$ & \\
\hline $\mathrm{SC} 1, \mathrm{SC} 2$ & & Jun \& Oct 1991-93 & & $\mathrm{x}$ \\
\hline Macroalgae & Directed suction sampling & & & \\
\hline $\mathrm{B} 1, \mathrm{~B} 2, \mathrm{~B} 3$ & & Feb 1993 & $x$ & \\
\hline $\mathrm{B} 1, \mathrm{~B} 2$ & & Mar 1993 & $x$ & \\
\hline Seagrass & Directed suction sampling & & & \\
\hline $\mathrm{SC} 1, \mathrm{SC} 2$ & & Feb 1993 & $\mathrm{x}$ & \\
\hline Sand & Directed suction sampling & & & \\
\hline $\mathrm{B} 1, \mathrm{~B} 2$ & & Feb 1993 & $\mathrm{x}$ & \\
\hline Macroalgae & Random suction sampling & & & \\
\hline $\mathrm{B} 1, \mathrm{~B} 2$ & & Mar 1993 & $\mathrm{x}$ & \\
\hline $\mathrm{B} 1, \mathrm{~B} 2, \mathrm{~B} 3, \mathrm{~B} 4$ & & Jan-Mar 1994 & $\mathrm{x}$ & \\
\hline Seagrass & Random suction sampling & & & \\
\hline $\mathrm{SC} 1, \mathrm{SC} 2, \mathrm{SR} 1, \mathrm{SR} 2$ & & Feb 1994 & $x$ & \\
\hline
\end{tabular}

tion (Barraterre Bay; Fig. 1) was located in a shallow ( 2 to $3 \mathrm{~m}$ ), mangrove-lined lagoon $\left(16 \mathrm{~km}^{2}\right)$ composed of patches of algae (primarily Batophora spp. and Laurencia spp.) and seagrass (Thalassia testudinum), interspersed among small ( 2 to $18 \mathrm{~cm}$ ), branching corals (primarily Porites spp.) and coarse calcareous sand. The second location (Sugar Cay Bay; Fig. 1) was located approximately $6 \mathrm{~km}$ seaward of Barraterre Bay and separated from it by the northern tip of Great Exuma. Sugar Cay Bay $\left(20 \mathrm{~km}^{2}\right)$ was composed of a shallow (2 to $3 \mathrm{~m}$ ), relatively homogeneous seagrass ( $T$. testudinum) meadow of moderate density $\left(\bar{x}=396\right.$ shoots $\mathrm{m}^{-2}, \mathrm{SD}=105, \mathrm{~N}=$ 12) that extended onto a very shallow $(0.5 \mathrm{~m})$ sand shoal to the north and contained patch coral heads in the center (Fig. 1). Seagrass density was quantified by tossing a $0.25 \mathrm{~m}^{2}$ quadrat haphazardly along transects that transversed the length and width of Sugar Cay Bay. Individual seagrass shoots within a quadrat were counted by SCUBA divers. In February 1994, a second seagrass location (Shark Rock; Fig. 1) was surveyed immediately after a large, onshore pulse of late

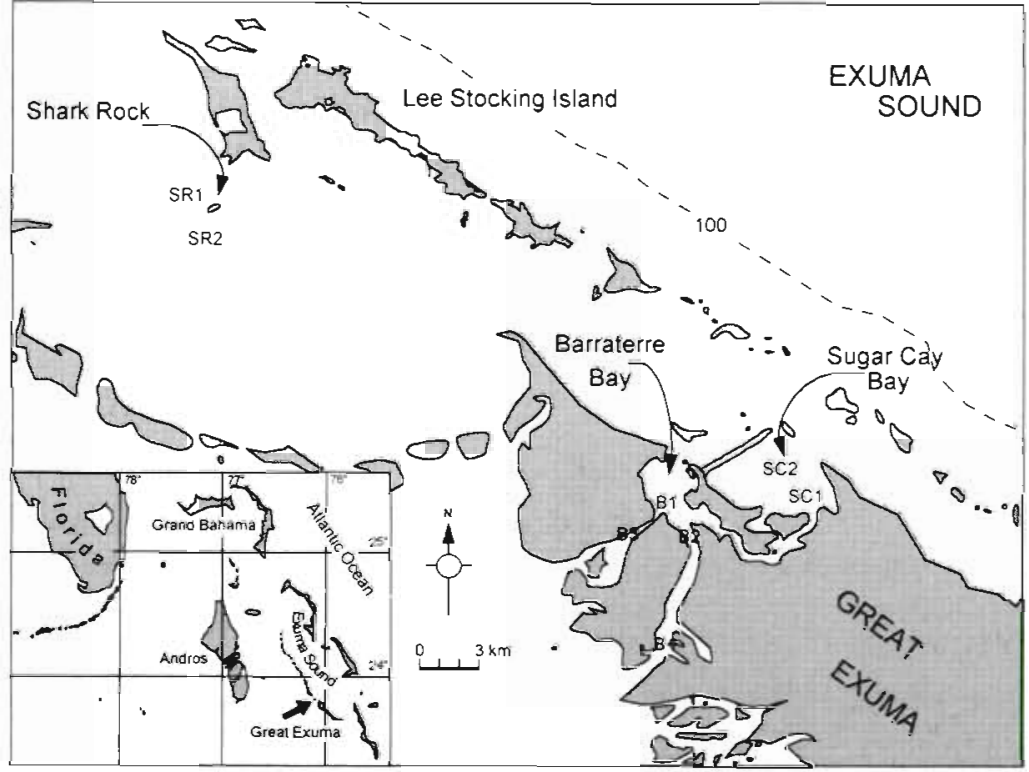

Fig. 1. Study sites near Lee Stocking Island, Bahamas. Sites at Barraterre Bay denoted by B1, B2, B3, and B4. Sites in Sugar Cay Bay and Shark Rock denoted by SC1 and SC2, and SR1 and SR2, respectively

larval-early juvenile Epinephelus striatus (ca 4000 fish) was collected in a single plankton net positioned in a tidal pass just northwest of LSI [A. Stoner, Caribbean Marine Research Center (CMRC), pers. comm.]. Shark 
Rock was positioned in the same tidal flow field as the plankton net indicated above. During flood tide, oceanic waters flow in an 'S'-shaped pattern originating from the inter-island pass northwest of LSI, and westward past Shark Rock (Fig, 1). Shark Rock habitats contained moderate to high densities of seagrass (ca 650 shoots $\mathrm{m}^{-2}, \mathrm{SD}=159, \mathrm{~N}=12$ ) covering approximately $20 \mathrm{~km}^{2}$. Seagrass density was quantified as outlined above for Sugar Cay Bay. Between 2 and 4 replicate sites positioned approximately $1 \mathrm{~km}$ apart were chosen within each location to quantify habitat use in juvenile Nassau grouper (Fig. 1). This resulted in 2 seagrass locations (Sugar Cay Bay and Shark Rock) containing 2 sites each, and 1 macroalgal location (Barraterre Bay) containing 4 sites (Fig. 1). Despite extensive searching, macroalgal systems that were similar to Barraterre Bay, yet geographically isolated, were not found within the vicinity of LSI. All locations were subject to strong tidal currents, sometimes exceeding $50 \mathrm{~cm} \mathrm{~s}^{-1}$, and high water visibility (ca 10 to $20 \mathrm{~m}$ ). Water temperatures ranged from ca $21^{\circ} \mathrm{C}$ in February to $30^{\circ} \mathrm{C}$ in August. Salinity ranged from 36 to 40 ppt.

Habitat utilization of early juvenile Nassau grouper. Early juvenile Epinephelus striatus were first observed residing next to algal-covered coral clumps at Site B1 of Barraterre Bay (Fig. 1) in May 1991. Densities of grouper at this site were subsequently measured by SCUBA divers using visual census techniques. The area was divided into 8 bands of $10 \times 60 \mathrm{~m}$ using floats attached to blocks. Six separate band transects (ca $60 \times$ $2 \mathrm{~m}$ ) were then randomly chosen from the 8 possible bands. All counts within a band were made by 2 divers and during daytime slack tides (10:00 to 14:00 h) when water visibility exceeded $10 \mathrm{~m}$. Individual fish residing next to an algal clump would usually swim into a clump as a diver approached. Thus, all replicate transects were slow and methodical, with observers attempting to locate concealed fish within algal clumps. Total fish length (mm TL), percent algal cover, and type of occupancy displayed (solitary versus grouped) was recorded for each transect. Fish fork lengths in $\mathrm{mm}$ were estimated by comparing fishes to a ruler attached perpendicular to the far end of a $70 \mathrm{~cm}$ rod held out from a diver (e.g. Bohnsack \& Bannerot 1986). This device helped avoid underwater magnification problems in estimating fish sizes and aided in delineating the $2 \mathrm{~m}$ band width. Percent algal cover within a transect $\left(120 \mathrm{~m}^{2}\right)$ was estimated to the nearest $5 \%$ visually by each of the 2 divers. Mean percent algal cover from the diver estimates was then used in statistical analyses (see below). The visual census for grouper and percent algal cover was duplicated in June.

Band transects were performed at 2 macroalgal sites (B1 and B2), as well as at 2 seagrass sites ( $\mathrm{SC} 1$ and
SC2), during June 1992-93 (Table 1, N = 6 for each site in all years). Since no early juvenile Epinephelus striatus were observed in seagrass habitats (SC1 and SC2) in June 1992-93 (see 'Results'), grouper density (no. per $120 \mathrm{~m}^{2}$ ) in macroalgal habitats was compared only across years and sites with analysis of covariance models using percent algal cover as the covariate and year (1992-93) and site (B1 vs B2) as independent factors. Band transects were also performed at the B1 site in June and October, 1991-93 (Table 1) to assess ontogenetic emigration from the Barraterre Bay nursery system. In this case, the effects of year, month and percent algal cover on Epinephelus striatus density were determined with a 2-way ANCOVA with year (1991-93) and month (June vs October) as factors, and percent algal cover as the covariate. Grouper density was $\log (x$ +1 )-transformed to meet assumptions of normality and homogeneity of variance; the assumption of equal slopes (Underwood 1981) was met in both data sets. To determine if annual or monthly patterns in grouper density were similar to those for algal abundance (e.g. Carr 1994), percent algal cover was used as the response variable in a 2-way ANOVA with year (1991-93) and month (June vs October) as factors. Differences between means in all cases were revealed by use of Ryan's $Q$ multiple comparison test (Einot \& Gabriel 1975) as recommended by Day \& Quinn (1989).

Previous observations suggested that early juvenile grouper reaching lengths $>150 \mathrm{~mm}$ TL consistently recruited to patch-reef habitats surrounding LSI in the early fall (R. Wicklund, CMRC, pers. comm.). Ontogenetic habitat shifts in this study were inferred by comparing temporal changes in abundance patterns of grouper $<150 \mathrm{~mm}$ TL residing in macroalgal habitats at Site B1, with temporal changes in abundance patterns in artificial reefs located seaward at Sites SC1 and SC2 (Fig. 1; Table 1). In this case, the June sampling date corresponded to the time when post-settlement grouper apparently emerge from macroalgal habitats, thereby facilitating quantification with visual census techniques. The October sampling date corresponded to a dramatic decrease in grouper abundance in Barraterre Bay, suggestive of emigration from macroalgal habitats.

Grouper densities in artificial patch reefs were assessed using spiny lobster shelters known as 'casitas Cubanas' (Eggleston et al. 1990). Casitas are scaled, concrete artificial reefs that simulate natural patch reefs (Eggleston et al. 1990) and have been used to manipulate shelter availability in different habitats (Eggleston \& Lipcius 1992). Divers censused 16 to 24 casitas at Sugar Cay Bay using a modification of Bohnsack \& Bannerot's (1986) stationary visual census technique. Fish fork lengths in mm were estimated by com- 
paring fishes to a ruler as described above. Grouper abundance in casitas at Sugar Cay Bay was compared between June and October and across years with a repeated measures ANOVA model; year was the repeated measure (1991-93), month (June vs October) was the factor, and the mean number of grouper (<150 mm TL) per casita was the response variable.

Settlement habitats. A benthic suction pump (e.g. Orth \& van Montfrans 1987) was used to quantify grouper density in macroalgal, seagrass, and sand habitats (1993 only) during January to March settlement periods in 1993-94. Two sampling approaches were used in 1993: (1) a directed, 'retrospective sampling approach' (sensu Agresti 1990, p. 12 to 19), which presumably had a higher probability of capturing postsettlement grouper than a more random survey design; and (2) a random approach. During 1994, only the random approach was used. The directed sampling approach involved placing a $1 \mathrm{~m}^{2}$ plastic quadrat on the largest clumps of algae and coral observed, or the most architecturally complex seagrass areas (e.g. containing sponges and algae), and then suctioning for $5 \mathrm{~min}$ into a $3 \mathrm{~mm}$ mesh collecting bag. The random sampling approach involved tossing a $1 \mathrm{~m}^{2}$ plastic quadrat into 6 to 8 out of 12 randomly chosen $10 \times 60 \mathrm{~m}$ bands followed by suctioning. The 12 bands were chosen and marked as described above for early juveniles.

The suction sampler removed surface sediment and debris to depths of $4 \mathrm{~cm}$, separating most algal macrophytes from the substrate, but leaving seagrass Halimeda spp. and some corals. A mesh, cylindrical frame usually used to retain organisms within the sampling area (e.g. Orth \& van Montfrans 1987) was not used in this study since high water clarity allowed continual observation of the entire sampling area, and fish were easily observed leaving the quadrat. On 2 occasions, grouper were observed fleeing algal clumps as they were being sampled; these fish were included in density estimates but not size estimates. Fish were livesorted, counted, measured to the nearest $0.1 \mathrm{~mm} \mathrm{TL}$, and released.

During February 1993, after an onshore pulse of late larval-early juvenile Nassau grouper [J. Shenker, Florida Institute of Technology (FIT), pers. comm.], eight or nine $1 \mathrm{~m}^{2}$ directed suction samples were taken at each of 3 macroalgal sites (B1, B2, and B3) and 2 seagrass sites (SC1 and SC2; Fig. 1). To determine whether grouper were settling in habitats without complex, benthic macroalgae, 8 suction samples were taken in a directed manner in areas of both B1 and B2 that were completely devoid of structure (i.e. primarily in coarse calcareous sand). Thus, a total of $60 \mathrm{~m}^{2}$ was suction sampled in February 1993 (Table 1).

During March 1993, macroalgal Sites B1 and B2 were sampled in both a directed and random manner
(Table $1, N=6$ per site per sampling technique). Seagrass, sand, and Site B3 were not sampled because no grouper were found there in February. For each $\mathrm{m}^{2}$ sample, habitat characteristics within the quadrat, such as sponges, holes, ledges and stony corals, were quantified. Chlorophycean and rhodophycean algae removed by suctioning were measured volumetrically. All volume measurements were taken above water using the natural packing of the algal clumps. During March 1993 a total of $24 \mathrm{~m}^{2}$ was sampled (12 directed $x$ 12 random $\times 2$ sites; Table 1 ).

A forward, stepwise multiple regression model was used to examine the relationship between habitat features at Site B1 in March 1993 and post-settlement grouper density; Site B2 was eliminated from this analysis because grouper were absent there in March. The regression model included as independent variables: (1) algal displacement volume (in l); (2) the total number of physical structures (i.e. number of corals + holes + ledges + sponges); (3) percent algal cover; and (4) number of individual corals. Alpha to enter and remove factors from the model was 0.15 . Dependent variables included density and volume estimates from the random sampling approach $(\mathrm{N}=6)$.

During January 1994, before any measured onshore transport of late larval-early juvenile Epinephelus striatus near LSI (A. Stoner pers. comm.), 8 random suction samples were taken at all 4 sites in Barraterre Bay (B1, B2, B3, B4; Fig. 1; Table 1). During February 1994, 3 d after a major influx of late larval-early juvenile E. striatus had been recorded near LSI (A. Stoner pers. comm.), 8 random suction samples were taken at each of 4 macroalgal (B1, B2, B3, B4) and seagrass (SC1, SC2, SR1, SR2) sites (Fig. 1). During March 1994,8 random samples were taken at the 4 macroalgal sites in Barraterre Bay but not seagrass sites since no grouper were collected there in February. Habitat characteristics were also quantified as described above. Thus, during 1994, a total of 32,64 , and $32 \mathrm{~m}^{2}$ was suction sampled in January, February and March, respectively (Table 1).

The effects of site, date and habitat features on postsettlement grouper density at Barraterre Bay during 1994 were examined with a 2-way analysis of covariance using site (B1, B2, B3, B4) and month (February vs March) as factors, habitat features (1) algal displacement volume (in 1); (2) the total number of physical structures (i.e. number of corals + holes + ledges + sponges): (3) percent algal cover; and (4) coral displacement volume (in 1)] as covariates, and grouper $\mathrm{m}^{-2}$ as the response variable. Grouper density was $\log (x+1)$-transformed to meet assumptions of normality and homogeneity of variance. Each of the habitat features also served as response variables in 4 separate 2-way ANOVA models with site (B1, B2, B3, B4) and 
month (February vs March) as factors. Macroalgal sites sampled in January and seagrass sites sampled in February were eliminated from the analysis because no grouper were collected. To determine whether grouper were settling on patch reefs, a stationary visual census for post-settlement juveniles was performed monthly on casitas located in Sugar Cay Bay during January to March, 1991-93 (Table 1).

A mark-recapture study assessed habitat-specific efficiency of suction sampling in March 1994. Postsettlement Epinephelus striatus $(\bar{x}=32.6 \mathrm{~mm} \mathrm{TL}, \mathrm{SD}=$ $2.1, N=24$ ) previously captured by suctioning were held in laboratory aquaria with running seawater for 1 to $2 \mathrm{~d}$ and marked by clipping either the dorsal or anal fin. After an additional 1 to $2 \mathrm{~d}$ acclimation period, fish were transported to either macroalgal Site B1, or seagrass Site SR1. Before releasing grouper adjacent to a particular substrate, a plastic, $1 \mathrm{~m}^{2}$ quadrat was tossed into a randomiy chosen $10 \times 60 \mathrm{~m}$ area as described above. SCUBA divers then released 4 marked fish adjacent to macroalgae or seagrass and observed their behavior for $10 \mathrm{~min}$ before recapturing them with the suction pump. This procedure was repeated 3 times at each site.

Relationship between habitat features and Nassau grouper density. Because variation in percent algal cover contributed significantly in the multiple regression and ANCOVA models of Nassau grouper density (see 'Results'), statistical identification of the functional relationship between percent algal cover and Epinephelus striatus density (i.e. hyperbolic, sigmoid) was examined with a linearized adaptation of a general functional response model derived by Real (1977. 1979):

$$
N_{\mathrm{a}}=K \times N_{\mathrm{t}}^{B} / X+N_{\mathrm{t}}^{B}
$$

where $N_{a}=$ grouper density, $K=$ the maximum density of grouper, $N_{\mathrm{t}}=$ initial percent algal cover, $X=$ the density of grouper at which $N_{\mathrm{a}}=0.5 \mathrm{~K}$, and $B=$ the parameter associated with the form of the curve or relationship (Real 1979). When $B=0$, the slope is zero, when $B$ $=1$, the curve is hyperbolic (decelerating rise to an asymptote), and when $B>1$, the curve is sigmold (Real 1979). Thus, a statistical test of the parameter $B$ is also a test of the form of the relationship between percent algal cover and grouper density. Estimates of $B$ were tested against 0 and 1 with 1 -tailed t-tests. Application of the general functional response model (Eq. 1) has been used successfully to corroborate the shape of functional response curves (i.e. hyperbolic, sigmoid) that were identified through ANOVA and non-linear modelling techniques (e.g. Lipcius \& Hines 1986, Eggleston 1990) and to identify the form of the relationship between prey survival and increasing seagrass biomass (Lipcius et al. unpubl.).
The Real $(1977,1979)$ model approach was complemented by regression analysis with linear, exponential and power functions. Differences between the correlation coefficients of these functions were compared using Fisher's transformation (Zar 1984). The distribution of residuals about predicted values for all regressions was tested with binomial tests of full and partial data sets. Examination of partial data sets were used to identify systematic variation in residuals.

\section{RESULTS}

\section{Habitat-specific efficiency of suction sampling for post-settlement grouper}

Marked individuals released into macroalgal habitats immediately swam into algal clumps where they remained for the 10 min observation period. At 2 of 3 plots, resident unmarked post-settlement Epinephelus striatus chased newly released fish in and out of clumps for several minutes after introductions. Mean algal displacement volume was $0.88 \mathrm{I} \mathrm{m}^{-2}(\mathrm{SD}=0.24, \mathrm{~N}$ $=3$ ) and recapture efficiency was $100 \%$. Marked fish released into seagrass habitats immediately sought refuge next to sponges, corals or within seagrass blades. One fish was quickly attacked and eaten by a slippery dick wrasse Halichoeres bivittatus, $17 \mathrm{~cm} \mathrm{TL}$; this fish was excluded from analyses. One marked fish swam out of the frame area during suctioning. Thus, recapture efficiency in seagrass was $92 \%$. Mean seagrass density was 593 shoots $\mathrm{m}^{-2}(\mathrm{SD}=149, \mathrm{~N}=3)$.

\section{Post-settlement habitat utilization}

Directed and random suction sampling across all habitats in 1993 (February-March) indicated that recently settled fish $(\bar{x}=31.7 \mathrm{~mm} \mathrm{TL}, \mathrm{SD}=2.9, \mathrm{~N}=31)$ resided primarily within coral clumps (Porites spp.) covered by masses of macroalgae (primarily the red alga Laurencia spp.). All grouper were in the initial stages of developing juvenile pigmentation (i.e. transitional between transparent and opaque coloration with some visible bars) Grouper were sometimes extracted from small holes in the sediment adjacent to algal-covered coral branches The algae and coral matrix also supported high densities and a diverse group of xanthid crabs, hippolytid shrimp, bivalves, gastropods and other small, potential prey for the grouper (author's unpubl. data).

During February 1993, post-settlement Epinephelus striatus density ranged from 0 to 8 fish $\mathrm{m}^{-2}$ during suction samples in which the quadrat was placed directly on the largest algal clumps. Mean densities were 2.12 fish $\mathrm{m}^{-2}(\mathrm{SD}=1.96, \mathrm{~N}=9)$ at Site $\mathrm{B} 1$, and 0.83 fish 
$\mathrm{m}^{-2}(\mathrm{SD}=0.75, \mathrm{~N}=8)$ at Site B2. During March 1993, fish were found only at Site B1, where mean densities were 0.58 fish $\mathrm{m}^{-2}(\mathrm{SD}=0.28, \mathrm{~N}=6)$ and 0.37 fish $\mathrm{m}^{-2}(\mathrm{SD}=0.57, \mathrm{~N}=6)$ using the directed and random approaches, respectively. Macroalgal clumps (primarily Laurencia spp.) at Sites B1 and $\mathrm{B} 2$ were patchily distributed at 2 to $3 \mathrm{~m}$ depths in substrates characterized by numerous sponges and stony corals, with some holes and ledges (Table 2). Stony corals (primarily Porites spp.) provided attachment sites for red algae since direct holdfast attachment was probably inhibited by heavy layers of coarse calcareous sand and minor amounts of silt and detritus Although mean post-settlement grouper density was higher at B1 than B2, overall habitat complexity was apparently higher at B2 than B1 (Table 2). In March 1993, there was no difference in algal displacement volume between Sites B1 and B2 ( $t$-test: $t=-0.86$, df $=$ $10, p=0.41$ ), but percent algal cover and the numbers of corals, holes and ledges were all significantly higher at B2 than B1 ( $t$-test: all $p<0.04$ ). However, none of the habitat variables (i.e. algal displacement volume, percent algal cover, number of individual corals, number of holes and ledges) contributed significantly to the

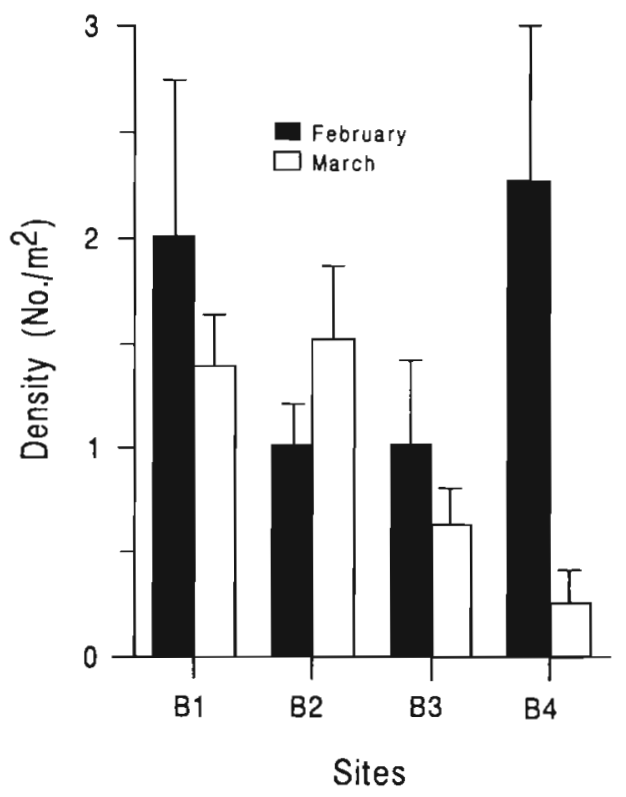

Fig. 2. Epinephelus striatus. Mean density (+ SE) of post-settlement Nassau grouper $(\bar{x}=31.7 \mathrm{~mm}$ TL) collected by suction sampling at macroalgal sites within Barraterre Bay during the onshore movement of late larval-early juvenile grouper in February and March 1994. Back-transformed values are displayed. $\mathrm{N}=8$ site $^{-1} \mathrm{mo}^{-1}$ multiple regression model ( $N=6$, Site $B 1$, random sampling approach).

During January 1994, before any measured onshore transport of late larval-early juvenile Epinephelus striatus had occurred near LSI (A. Stoner pers. comm.), no post-settlement grouper were collected in suction sampling at any of the 4 macroalgal sites in Barraterre Bay $(N=32)$. During February 1994, 3 d after a major influx of late larval-early juvenile $E$. striatus at LSI (A. Stoner pers. comm.), 55 post-settlement stage Nassau grouper $(\bar{x}=30.0 \mathrm{~mm} \mathrm{TL}, \mathrm{SD}=$ 1.1) were collected by suction sampling the same habitats ( $N=32)$. No grouper were collected in seagrass habitats at Sugar Cay Bay or Shark Rock ( $N=$ 32). E. striatus densities in macroalgae ranged from 0 to 7 fish $\mathrm{m}^{-2}$. During March 1994, 33 Nassau grouper were collected in the macroalgal sites in Barraterre Bay; densities ranged from 0 to 3 fish $\mathrm{m}^{-2}$, and mean size was $34.6 \mathrm{~mm}$ TL ( $\mathrm{SD}=2.6$ ). No post-settlement stage grouper were observed in casitas during January to March, 1991-93.

Post-settlement grouper density in macroalgae varied significantly as a function of a site $x$ date interaction effect (Fig. 2; ANCOVA: $F=3.58$, df = 3,28, p = 0.03 ), and according to percent algal cover (ANCOVA: $F=8.77, \mathrm{df}=1,28, \mathrm{p}=0.006$ ). None of the main effects, other habitat covariates, or covariate $\times$ factor interactions were significant (all $p>0.09$ ). The site $\times$ date interaction was due to significantly higher grouper densities at Sites B1 and B2 than at Sites B3 and B4 in March, and no significant difference between sites in February (Fig. 2; Ryan's Q multiple comparison test). In general, specific habitat features quantified within $\mathrm{m}^{2}$ quadrats during suction sampling varied significantly according to month (February vs March) and site (B1, B2, B3, B4) (Table 3); however, in every case, there was a significant month $\times$ site interaction effect, precluding contrasts among treatment means (Underwood 1981). Although there was no consistent trend to the month $x$ site interactions (Table 4), there was a tendency 
Table 3. Effects of sampling date in 1994 (February vs March) and site $(B 1, B 2, B 3, B 4)$ upon physical. resources quantified during suction sampling for post-settlement Epinephelus striatus. Response variables were: (1) percent algal cover; and log-transformed (2) algal displacement volume, (3) coral displacement volume, and (4) total. counts of physical structure (i.e. sponges, holes, and ledges)

\begin{tabular}{|c|c|c|c|c|}
\hline \multicolumn{5}{|c|}{ 2-way ANOVA table (model lj } \\
\hline Source of variation & SS & df & is & $F$ \\
\hline \multicolumn{5}{|l|}{ Percent algal cover } \\
\hline Month & 0.11 & 2 & 0.11 & $6.89 \cdots$ \\
\hline Site & 0.16 & 3 & 0.05 & $3.26^{\circ}$ \\
\hline Month $\times$ Site & 0.66 & 3 & 0.22 & $13.54 \cdots$ \\
\hline Error & 0.94 & 58 & 0.02 & \\
\hline \multicolumn{5}{|c|}{ Algal displacement volume } \\
\hline Month & 2.12 & 1 & 2.12 & $6.47^{\circ}$ \\
\hline Site & 6.17 & 3 & 2.06 & $6.27^{*}$ \\
\hline Month $\times$ Site & 5.83 & 3 & 1.94 & $5.93^{*}$ \\
\hline Error & 19.01 & 58 & 0.33 & \\
\hline \multicolumn{5}{|l|}{ Corals } \\
\hline Month & 0.01 & 1 & 0.01 & $0.01 \mathrm{NS}$ \\
\hline Site & 0.24 & 3 & 0.08 & $2.92^{\circ}$ \\
\hline Month $\times$ Site & 0.70 & 3 & 0.23 & $8.66^{\cdots}$ \\
\hline Error & 1.56 & 58 & 0.03 & \\
\hline \multicolumn{5}{|l|}{ Total structure } \\
\hline Month & 0.94 & 1 & 0.94 & $3.04 \mathrm{NS}$ \\
\hline Site & 0.86 & 3 & 0.29 & $0.93 \mathrm{NS}$ \\
\hline Month $\times$ Site & 2.85 & 3 & 0.95 & $3.08^{\circ}$ \\
\hline Error & 17.94 & 58 & 0.31 & \\
\hline
\end{tabular}

towards higher amounts of physical structure at the B4 site compared to other sites (Tables 4 \& 5). Percent algal cover was significantly higher at the B4 site in February, during the major recruitment period for late

Table 4. Ryan's $Q$ tests of physical resources for the month $x$ site interaction effects. Treatment levels that are not significantly different at the 0.05 level share an underline. Treatment levels are arranged in increasing order of abundance

\begin{tabular}{|c|c|c|c|c|}
\hline \multicolumn{2}{|c|}{ Interaction } & \multicolumn{2}{|c|}{ Site } & \\
\hline \multicolumn{5}{|c|}{ Percent algal cover } \\
\hline February & $\underline{B 1}$ & $\mathrm{~B} 2$ & $\mathrm{B3}$ & $\underline{B 4}$ \\
\hline March & $\underline{\mathrm{B} 4}$ & B2 & B3 & B1 \\
\hline \multicolumn{5}{|c|}{ Algal displacement volume } \\
\hline February & B2. & B1 & B3 & $\underline{B 4}$ \\
\hline March & B1 & B4 & $B 2$ & B3 \\
\hline \multicolumn{5}{|l|}{ Corals } \\
\hline February & B4 & B3 & $\underline{B 2}$ & B1 \\
\hline March & B3 & B1 & B2 & $\underline{\mathrm{B} 4}$ \\
\hline \multicolumn{5}{|c|}{ Total structure } \\
\hline February & $\underline{B 3}$ & $B 2$ & $\underline{B 4}$ & $\underline{B 1}$ \\
\hline March & B1 & $\mathrm{B} 3$ & B2 & B4 \\
\hline
\end{tabular}
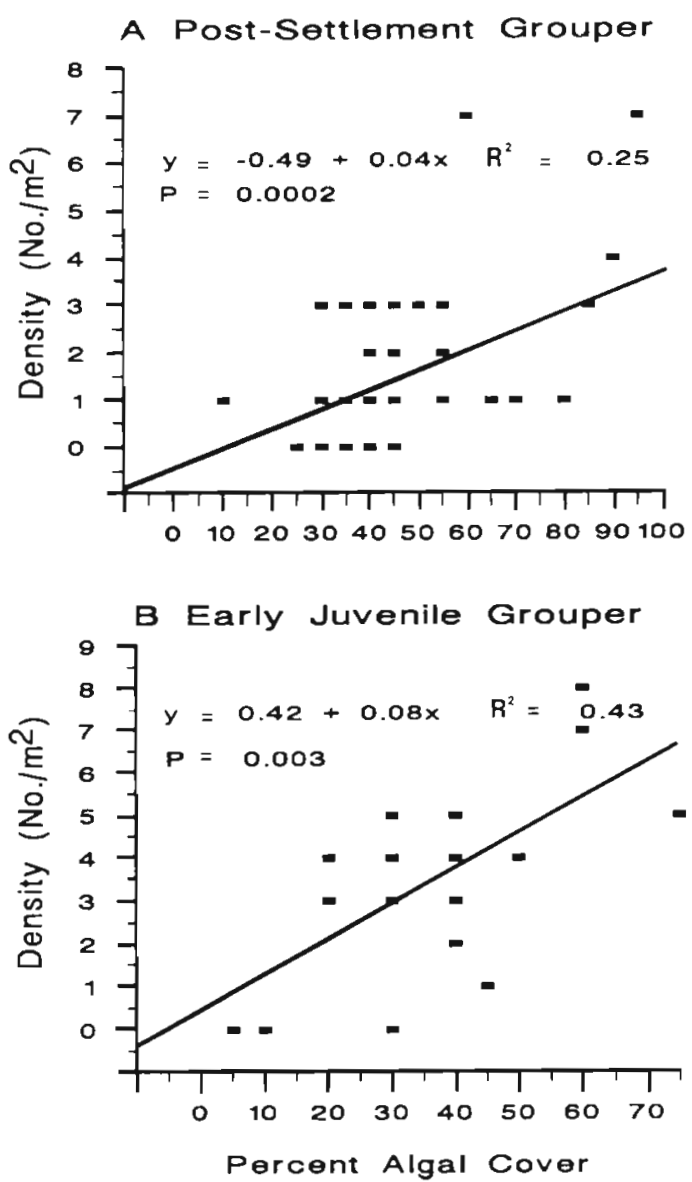

Fig. 3. Epinephelus striatus. Relationship between percent algal cover and: (A) post-settlement grouper densities, as measured by suction sampling at all 4 sites in Barraterre Bay in 1994 ( $N=32)$; (B) early juvenile densities measured with band transects $(N=18)$. March data are excluded in $(A)$ due to significant differences in grouper abundance between sites. (B) is based on data from Site B1 in 1991 and Sites B1 and B2 in 1993. B2 is included because of no difference in grouper abundance between sites in 1993, and 1992 data were excluded due to low overall grouper abundance

larval-early juvenile Epinephelus striatus, than at other sites in Barraterre Bay (Table 4). Analysis of the form of the relationship (Eq. 1) between percent algal cover and grouper density at all 4 sites in Barraterre Bay in February 1994 (Fig. 3A) initially indicated a positive linear or hyperbolic relationship, with $B(1.25)$ significantly different from 0 but not 1 (Table 6). Fisher's transformation (Zar 1984) indicated that exponential and power functions did not significantly improve the fit of the data over a linear function (all $p>0.65$ ). Thus the simplest model (positive linear) was chosen to describe the form of the relationship between increasing percent algal cover and post-settlement $E$. striatus density (Fig. 3A). 
Table 5. Abundance estimates of physical resources in Barraterre Bay taken with the random toss sampling method in February and March 1994. Shown are mean numbers (simple counts or volume, in l) per $\mathrm{m}^{2}$; standard deviations given in parentheses. $N=8$ per site. Note that coral abundance was measured as displacement volume (l), and total physical structure included counts of sponges, holes and ledges

\begin{tabular}{|c|c|c|c|c|}
\hline \multirow[t]{2}{*}{ Resource } & \multicolumn{4}{|c|}{ Site } \\
\hline & B1 & B2 & B3 & $B 4$ \\
\hline \multicolumn{5}{|l|}{ February } \\
\hline Laurencia spp." & $0.95(0.57) 1$ & $0.64(0.21) 1$ & $1.35(0.57) 1$ & $3.14(1.30) 1$ \\
\hline Stony corals & $0.39(0.37) 1$ & $0.33(0.19) \mathrm{l}$ & $0.10(0.06) 1$ & $0.00(0.00) 1$ \\
\hline Total structure & $1.89(1.27)$ & $0.88(1.07)$ & $0.63(0.74)$ & $1.25(1.28)$ \\
\hline$\%$ Algal cover & $38.3(16.2)$ & $40.7(3.5)$ & $45.0(13.4)$ & $75.6(17.4)$ \\
\hline \multicolumn{5}{|l|}{ March } \\
\hline Laurencia spp. ${ }^{d}$ & $0.73(0.34) 1$ & $0.90(0.47) \mathrm{l}$ & $1.24(0.61) 1$ & $0.93(0.57)]$ \\
\hline Stony corals & $0.08(0.06) \mathrm{l}$ & $0.28(0.39) \mathrm{l}$ & $0.59(0.57) \mathrm{l}$ & $0.42(0.24)]$ \\
\hline Total structure & $0.30(0.21)$ & $1.00(1.50)$ & $0.75(1.34)$ & $1.63(2.07)$ \\
\hline$\%$ Algal cover & $45.0(19.5)$ & $43.5(8.80)$ & $45.0(6.50)$ & $32.5(5.30)$ \\
\hline \multicolumn{5}{|c|}{ a Included minor amounts (ca $0.01 \mathrm{l}$ ) of Batophora spp. } \\
\hline
\end{tabular}

Table 6. Linear regression results of log-transformed general functional response models (Real 1977, 1979) for identifying the form of the relationship between percent algal cover and grouper density. The transformed dependent variable met assumptions of normality and equality of variance

\begin{tabular}{|c|c|c|}
\hline Feature & Post-settlers & Early juveniles \\
\hline \multicolumn{3}{|l|}{ Parameter estimates } \\
\hline Intercept & -0.06 & -3.18 \\
\hline Slope & 1.25 & 2.08 \\
\hline \multicolumn{3}{|l|}{ Slope standard } \\
\hline Error & 0.60 & 0.63 \\
\hline \multicolumn{3}{|l|}{ Summary statistics } \\
\hline Regression SS (df) & $1.75(1)$ & $5.17(1)$ \\
\hline Residual SS (df) & $15.43(38)$ & $6.68(14)$ \\
\hline$F$-value & $4.31^{\circ}$ & $10.83^{\cdots}$ \\
\hline $\mathrm{R}^{2}(\%)$ & 10.1 & 43.6 \\
\hline \multicolumn{3}{|l|}{ Tests of hypotheses } \\
\hline$H_{0}:$ slope $=0$ & $\cdot$ & $\cdots$ \\
\hline$H_{0}:$ slope $=1$ & NS & NS \\
\hline \multicolumn{3}{|c|}{$\cdot p<0.04 ; \cdots p<0.006 ;$ NS: $p>0.05$} \\
\hline
\end{tabular}

\section{Early juvenile habitat utilization}

Early juveniles $(\vec{x}=85.0 \mathrm{~mm}$ TL, $\mathrm{SD}=11.7, \mathrm{~N}=65)$ were observed within or adjacent to algal-covered coral clumps by divers swimming in the band transects during June 1991-93 (4 to 5 mo after settlement in each year). Densities ranged from 0 to 0.06 fish $\mathrm{m}^{-2}$. Most grouper were solitary (88\%); grouped individuals were always in pairs. No early juvenile Epinephelus striatus were observed in seagrass habitats at Sugar Cay Bay during June 1991-93. In assessing the repeatability of density estimates in macroalgae using the visual censusing technique, the covariate (percent algal cover) was significant (ANCOVA; algae: $F=64.57, \mathrm{df}=$ $1,8, p=0.001$ ), and there was no significant difference in early juvenile grouper density between May and June $1991(F=1.59$, df $=1,8, \mathrm{p}=0.24)$. Thus, the band transects appeared to be a reliable method for estimating the density of early juvenile Nassau grouper in these algal habitats.

The density of early juveniles at Site $B 1$ varied significantly as a function of year and month (2-way ANCOVA; year: $F=7.31$, df $=2,24, p=0.003$; month: $F=17.21$, df $=1,24, \mathrm{p}=0.001$ ), and according to percent algal cover ( $F=19.84$, df $=1,24, p=0.001)$. There were significantly more grouper in 1991 and 1993 than in 1992, and significantly more in June than in October (Fig. 4A; Ryan's Q multiple comparison test). In all 3 years, grouper density declined 87 to $100 \%$ from June to October (Fig. 4A). None of the factor or covariate by factor interactions were significant (all $p>0.12$ ). Mean percent algal cover remained consistent at approximately $30 \%$, irrespective of year (1991-93) or month (June vs October) (2-way ANOVA; year: $F=0.01, \mathrm{df}=2,30, \mathrm{p}=0.99$, month: $F=0.04, \mathrm{df}=$ $1,30, \mathrm{p}=0.85)$. The interaction was not significant $(F=$ 0.01 , df $=2,30, p=0.99$ ). For the 2 years in which densities were relatively high $\left(\bar{x}=0.03\right.$ fish $\mathrm{m}^{-2}$ in 1991 and 1993), the form of the relationship between percent algal cover and early juvenile density (Fig. 3B) was also positive linear or hyperbolic, with $B(2.08)$ significantly different from 0 but not 1 (Table 6). Fisher's transformation (Zar 1984) again indicated that exponential and power functions did not significantly improve the fit of the data over a linear function (all $p>$ 0.45). Thus, the simplest model (positive linear) was also chosen to describe the form of the relationship between increasing percent algal cover and early juvenile densities (Fig. 3B). In 1992-93, there was no significant difference in Epinephelus striatus densities between Sites B1 and B2 (ANCOVA; site: $F=0.02$, df $=$ $1,16, p=0.88$ ).

The significant decrease in grouper density from June to October at macroalgal Site B1 in all years corresponded to increases in grouper abundance at casitas in seagrass beds near Sugar Cay Bay (compare Figs. 3 \& 4). The mean number of early juvenile grouper $<150 \mathrm{~mm}$ TL inhabiting casitas varied signifi- 

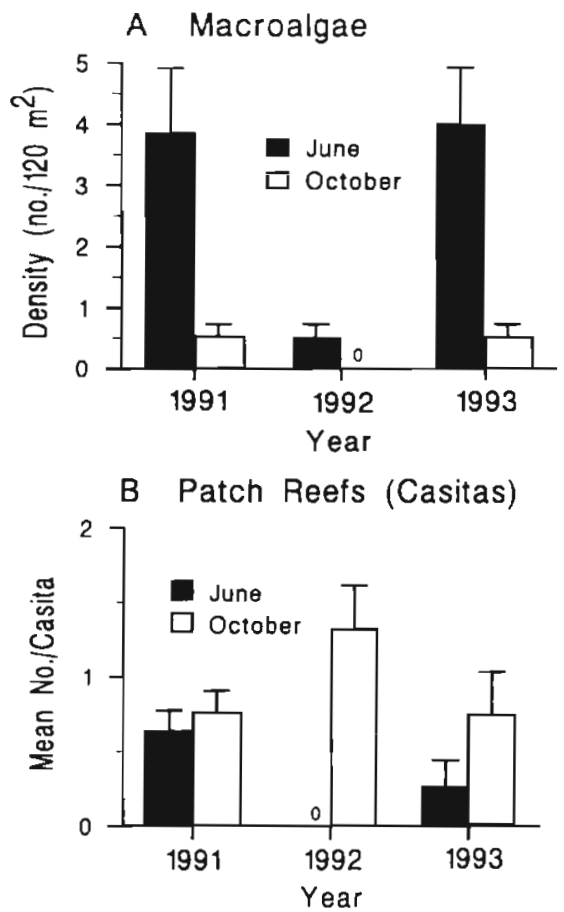

Fig. 4. Epinephelus striatus. Mean densities (+ SE) of early juvenile Nassau grouper ( $<150 \mathrm{~mm}$ TL, $\bar{x}=85.0 \mathrm{~mm}$ TL) as a function of year and month measured: $(A)$ at the first site in Barraterre Bay (B1) with band transects $\left(\mathrm{N}=6 \mathrm{mo}^{-1}\right)$; and (B) in casitas located in seagrass flats at Sugar Cay Bay $(\mathrm{N}=16$ to $24 \mathrm{mo}^{-1}$ ). Back-transformed values are displayed. See text for significance levels

cantly as a function of month, but not by year (repeated measures ANOVA, month: $F=13.37$, df $=1,26, p=$ 0.001 ; year: $F=1.93, \mathrm{df}=2,52, p=0.16$ ). However, the year $\times$ month interaction effect was significant $(F=$ $3.62, \mathrm{df}=2,52, \mathrm{p}=0.04)$, precluding direct contrasts across the month main effect. The year $x$ month interaction effect was due to significantly higher numbers of juvenile grouper per casita in October 1992-93 than in June of both years, compared to no significant difference in abundance between months in 1991 (Fig. 4; Ryan's $Q$ multiple comparison test).

\section{DISCUSSION}

This study documents natural settlement habitat during the wintertime, onshore movement of late larval-early juvenile Nassau grouper, and an apparent ontogenetic habitat shift by early juveniles. Habitat associations of post-settlement Nassau grouper have probably remained undescribed due to their sparse distribution, cryptic coloration, and association with structurally complex bottoms, all of which preclude adequate sampling by conventional methods. Suction sampling in macroalgal, seagrass, and coarse calcareous sand habitats in 1993-94, as well as visual surveys at artificial patch reefs in 1991 to 1993, revealed that recently settled grouper resided exclusively within coral clumps (Porites spp.) covered by masses of macroalgae (primarily Laurencia spp.). Stands encompassing separate algal clumps harbored up to 8 postsettlement grouper. The algal-covered coral clumps formed an open lattice that facilitated the movement of individuals within the interstices of the clumps. Percent algal cover within the Barraterre Bay macroalgal system was correlated with post-settlement grouper density; other habitat characteristics such as algal displacement volume, and the numbers of holes, ledges, and corals were not. The functional relationship between percent algal cover and post-settlement density was linear and positive

Band transects performed 4 to 5 mo after the settlement period (June 1991-93) indicated that early juveniles were residing solitarily $(88 \%)$ within or adjacent to algal-covered coral clumps; during the sampling period mean size in 1993 increased from 31.7 to $85.0 \mathrm{~mm}$. TL (ca $10 \mathrm{~mm} \mathrm{mo}^{-1}$ ). Growth rates observed in this study are consistent with those reported for early juvenile Epinephelus striatus inhabiting artificial patch reefs off St. Thomas, U.S. Virgin Islands $(8$ to $12 \mathrm{~mm}$ TL $\mathrm{mo}^{-1}$; Beets \& Hixon in press). When densities of early juveniles were relatively high in 1991 and 1993 ( $\bar{x}=$ 0.03 fish $\mathrm{m}^{-2}$ in both years), percent algal cover and grouper density were also positively correlated.

The correspondence between the significant decrease of early juvenile density in macroalgal habitats of Barraterre Bay from June to October, 1991-93, and the increase in abundance of juveniles at casitas located in seagrass meadows at Sugar Cay Bay was consistent with an ontogenetic habitat shift in the juvenile phase. Hence, Epinephelus striatus were classified into 3 stages based on habitat associations observed in this study: (1) post-settlement fish (25 to $35 \mathrm{~mm}$ TL) residing exclusively within algae-covered coral clumps; (2) early juveniles (60 to $150 \mathrm{~mm}$ TL) residing outside of and adjacent to algae-covered coral clumps; and (3) larger juveniles (>150 mm TL), which were generally associated with natural and artificial patch reefs.

\section{Settlement habitats}

Habitat preferences of the smallest juvenile reef fishes observed are often inferred through detailed examination of small-scale distribution patterns (e.g. Jones 1984, Sale et al. 1984, McFarland et al. 1985, Victor 1986, Shapiro 1987, Robertson et al. 1988, DeMartini \& Roberts 1990, Levin 1991) Post-settlement grouper collected with suction sampling in this study ranged 
from 27 to $38 \mathrm{~mm} \mathrm{TL} \mathrm{(} \bar{x}=31.7 \mathrm{~mm} \mathrm{TL}$ ), corresponding with the size range of late larvae-early juveniles (18 to $30 \mathrm{~mm} \mathrm{TL}, \bar{x}=23.4 \mathrm{~mm}$ TL) collected with plankton nets as they moved from the pelagic environment of Exuma Sound, Bahamas, to shallow nursery habitats on Great Bahamas Bank (Shenker et al. 1993). The small grouper collected by suction sampling in the macroalgal habitats exhibited incomplete juvenile pigmentation and had likely settled recently.

Non-random habitat utilization by reef fish can result from several mechanisms including: (1) differential larval supply; (2) substrate selection by settlers; (3) differential post-settlement mortality; and (4) migration between habitats. The juveniles and adults of many coral reef fish are sedentary and do not emigrate from the settlement habitat except during ontogenetic habitat shifts (Sale et al. 1984, Shapiro 1987, Robertson 1988, Doherty 1991). Most studies of the mechanisms underlying recruitment success in reef fish have focused on substrate selection by settlers (Williams \& Sale 1981, Sale et al. 1984, Shulman 1984, Sweatman 1985, 1988, Shapiro 1987) and the relative importance of larval supply (Milicich et al. 1992, Meekan et al. 1993) versus post-settlement predation and competition under variable recruitment and mortality rates (Shulman \& Ogden 1987, Doherty 1991, Jones 1991). Preliminary measures of larval supply using grouper settlement on floating, artificial spiny lobster settlement substrates indicated similar settlement rates on substrates moored over seagrass sites at Sugar Cay Bay and Shark Rock, and substrates moored over macroalgal sites in Barraterre Bay (author's unpubl. data). Given a significant correlation between grouper settlement on artificial substrates and water column densities measured with plankton nets (author's unpubl data), recruitment success in macroalgae is due to active substrate selection behavior, post-settlement mortality or movements, or a combination of all 3 mechanisms.

\section{Alternative settlement habitats}

The present findings indicate that early juvenile Nassau grouper within the vicinity of Great Exuma, Bahamas, principally use macroalgal habitats at settlement and as a nursery during the subsequent 3 to 5 mo. However, macroalgal habitats in this study were limited to a single network of mangrove-lined channels, thereby confounding habitat and site effects. Thus, future studies of Epinephelus striatus settlement and post-settlement distribution should attempt to refute the apparent importance of macroalgal habitats observed in this study. Other habitats undoubtedly serve as settlement sites in areas lacking expansive macroalgal meadows. The apparent absence of postsettlement E. striatus in seagrass habitats was surprising given the role of seagrass beds as settlement and nursery habitats for marine fish in both temperate and tropical systems (Orth et al. 1984, Parrish 1989). Postsettlement $E$. striatus may have been distributed sparsely in the seagrass habitats such that suction sampling $49 \mathrm{~m}^{2}\left(17 \mathrm{~m}^{2}\right.$ in $1993+32 \mathrm{~m}^{2}$ in 1994) with an efficiency of ca $92 \%$ was inadequate to estimate their density.

In a related study, settlement habitat of gag grouper Mycteroperca microlepis off the southeastern coast of the United States was found to consist of complex microhabitats including seagrass meadows (Zostera marina and Halodule wrightii; Ross \& Moser 1995) and oyster reefs (Crassostrea virginica; Mullaney 1991). Similar to Mullaney's (1991) observations of gag grouper inhabiting oyster reefs, post-settlement Nassau grouper were observed during the winter of 1990 residing in rubble mounds surrounding several tilefish Malacanthus plumieri burrows offshore of Lee Stocking Island (P. Colin pers. comm.). Another potential settlement habitat includes animal burrows and small holes. For example, juvenile Epinephelus striatus ranging from 30 to $80 \mathrm{~mm}$ TL were observed in July 1988 in small burrows beneath the bases of artificial reefs near a seagrass meadow in the U.S. Virgin Islands (Beets \& Hixon in press). Several E. striatus were suctioned out of small holes beneath the algal canopy in this study. Mangrove Rhizophora spp. prop roots can also serve as refuge for recent settlers (e.g. Thayer et al. 1987, Morton 1990). Although early juvenile E. striatus were never observed adjacent to mangrove prop roots in this study, this habitat was not sampled quantitatively. The focus of the present study was to quantitatively sample for recent settlers in habitats where later-stage juveniles had been consistently observed.

\section{Relationship between habitat features and fish density}

There was a positive correlation between densities of post-settlement or early juvenile Nassau grouper and percent algal cover. An adaptation of a general functional response model was then used to define a statistical positive and linear relationship between percent algal cover and grouper density. Many studies in both marine and freshwater systems have demonstrated a positive correlation between plant biomass and fish density (Cooper \& Crowder 1979, Orth et al. 1984, Heck \& Crowder 1991, Levin 1991, Carr 1994, but see Worthington et al. 1992 for a contrasting view concerning shoot density). For example, recruitment of 
kelp bass Paralabrax clathratus in giant kelp Macrocystis pyrifera habitats offshore of Southern California, USA, varied in an asymptotic manner with increasing kelp density (Carr 1994). Corresponding field experiments indicated that kelp bass recruitment was linearly related to the local abundance of kelp structure (i.e. the number and biomass of overlapping Macrocystis spp. blades) (Carr 1994). Similarly, Levin (1991) found that post-settlement abundance of cunner Tautogolabrus adspersus in macrophyte-covered rubble habitats in the Gulf of Maine, USA, was positively associated with the presence of macrophytes and negatively associated with microhabitats of low structural complexity (i.e. low percent cover of various forms of macroalgae).

\section{Potential ontogenetic habitat shifts}

Ontogenetic habitat shifts are typically inferred through the size or age structure of populations in different places over time (Jones 1991). Some tropical reef fish settle in seagrass and mangrove-prop-root nursery habitats and subsequently migrate from these habitats to nearshore patch reefs and offshore reef habitats as they mature (Parrish 1989). For example, of the coast of St. Croix, U.S. Virgin Islands, haemulids typically settle in seagrass beds, followed by an ontogenetic migration to patch reefs as juveniles (McFarland 1979, Brothers \& McFarland 1981). The present findings suggest that early juvenile Nassau grouper (ca 120 to $150 \mathrm{~mm}$ TL) exhibit an ontogenetic movement from macroalgal clumps to patch reef habitats during the late summer and early fall after settlement in winter. This inference stems from the correspondence between a significant decrease in early juvenile densities in macroalgal habitats of Barraterre Bay from June to October 1991-93 and an increase in abundance at casitas in seagrass meadows at Sugar Cay Bay.

Fishes often benefit from a change in resource use as body size increases (Werner \& Gilliam 1984, Ebenman 1992). Increasing body size generally leads to increased foraging efficiency (MacKenzie ei al. 1990), reduced susceptibility to starvation (Miller et al. 1988), and decreased vulnerability to predators (Pepin et al. 1987. Miller et al. 1988). Size-specific shifts in trophic habits occur in various fish and are often associated with habitat shifts (Werner \& Gilliam 1984). Post-settlement Nassau grouper were either solitary or aggregated within isolated algal clumps, whereas early juveniles tended to be solitary residents ( $88 \%$ ) within or adjacent to algal clumps. Exclusive access to algal clumps in larger juveniles may have simultaneously reduced the foraging time required to meet nutritional demands and exposure to predators (e.g. Marx \& Herrnkind 1985).
The apparent departure of early juvenile Nassau grouper from macroalgal nursery habitats during the late summer and early fall may have been triggered by increasing metabolic demands and reduced predation risk with increasing body size, resulting in an expanding niche width during ontogeny (Werner \& Gilliam 1984). Conversely, crevice-dwelling juvenile grouper may face a decline in the availability of crevices as they grow (Steger 1987, Moran \& Reaka 1988, Eggleston et al. 1990), thereby creating a population bottleneck in certain nursery habitats (e.g. Caddy 1986). Once juvenile grouper recruited to casitas in the fall, they aggregated beneath casitas with as many as 25 juvenile conspecifics ranging in size from 160 to $350 \mathrm{~mm}$ TL (author's unpubl. data).

Clumps of highly-branched red algae Laurencia spp. serve as settlement habitat for postlarval Caribbean spiny lobster and as residence for early-benthic phase juveniles (Marx \& Herrnkind 1985, Herrnkind \& Butler 1986). Thus, extensive algal patches present throughout the Caribbean appear to be one of the major settlement and nursery sites for two of the most ecologically and commercially important species in this region: Caribbean spiny lobster and Nassau grouper. Reemphasis of the ecological and commercial importance of shallow, macroalgal habitats (e.g. Herrnkind et al. 1988) should help lead to better management of key fisheries and reduction of deleterious human activities such as channel construction, dredging, spoil dumping, and coastal development in these areas.

Acknowledgements. I am very grateful to $J$. Chaves, L. Coba, B. Patton, W. Elis, D. Nadeau, A. Adams, G. Williams, and G. Jensen for field assistance. Tremendous logistical support was provided by the staff at the Caribbean Marine Research Center as well as the Crustacean Ecology Program at the Virginia Institute of Marine Science. The manuscript was improved by thoughtful comments from J. Grover, R. Lipcius, B. Olla, S. Sogard, and 3 anonymous referees. This work was funded by the Caribbean Marine Research Center, National Undersea Research Center of the National Oceanic and Atmospheric Association; the College of Ocean and Fishery Sciences, University of Washington; North Carolina State University; and the College of William and Mary.

\section{LITERATURE CITED}

Agresti A (1990) Categorical data analysis. John Wiley \& Sons, Inc, New York, p 558

Bannerot SP, Fox WW Jr, Powers JE (1987) Reproductive strategies and the management of snappers and groupers in the Gult of Mexico and Caribbean. In: Polovina JJ, Ralston S (eds) Tropical snappers and groupers: biology and fisheries management. Westview Press, Boulder, $p$ $561-603$

Beets J, Hixon MA (In press) Distribution, persistence, and growth of groupers (Pisces: Serranidae) on artuficial and natural patch reefs in the Virgin Islands. Bull mar Sci

Bertness MD, Gaines SD, Stephens EG. Yund PO (1992) Com- 
ponents of recruitment in populations of the acorn barnacle Semibalanus balanoides (Linnaeus). J exp mar Biol Ecol 156:199-215

Bohnsack JA, Bannerot SP (1986) A stationary visual census technique for qualitatively assessing community structure of coral reef fishes. NOAA Tech Rep NMFS 41:1-15

Brothers EB, McFarland WN (1981) Correlations between otolith microstructure, growth, and life history transitions in newly recruited French grunts (Haemulon flavolineatum [Desmarest], Haemulidae). Rapp P-v Reun Cons int Explor Mer 178:369-374

Caddy JF (1986) Modelling stock-recrutment processes in Crustacea: some practical and theoretical perspectives. Can J Fish Aquat Sci 43:2330-2344

Carr MH (1989) Effects of macroalgal assemblages on the recruitment of temperate zone reef fishes. J exp mar B1ol Ecol 126:59-76

Carr MH (1994) Effects of macroalgal dynamics on recruit ment of a temperate reef fish. Ecology 75:1320-1333

Colin PL (1992) Reproduction of the Nassau grouper Epinephelus striatus (Pisces: Serranidae) and its relationship to environmental conditions. Environ Biol Fish 34: $357-377$

Cooper WE, Crowder LE (1979) Patterns of predation in simple and complex environments. In: Shoud RH, Clopper H (eds) Predator-prey systems in fisheries management. Sport Fisheries Institute, Washington, DC, p 257-267

Day RW, Quinn GP (1989) Comparisons of treatments after an analysis of variance in ecology. Ecol Monogr 59:433-463

DeMartini EE, Roberts DA (1990) Effects of giant kelp (Macrocystis) on the density and abundance of fishes in a cobble bottom kelp forest. Bull mar Sci 46:287-300

Doherty PJ (1991) Spatial and temporal patterns in recruitment. In: Sale PF (ed) The ecology of fishes on coral reefs. Academic Press, Inc, New York, p 261-293

Ebenman B (1992) Evolution in organisms that change their niches during the life cycle. Am Nat 139:990-1021

Eggleston DB (1990) Behavioural mechanisms underlying variable functional responses of blue crabs, Callinectes sapidus feeding on juvenile oysters, Crassostrea virginica. J Anim Ecol 59:615-630

Eggleston DB, Armstrong DA (1995) Pre-and post-settlement determinants of estuarine Dungeness crab recruitment. Ecol Monogr 65:191-254

Eggleston DB, Lipcius RN (1992) Shelter selection by spiny lobster under variable predation risk, social conditions, and shelter size. Ecology 73:992-1011

Eggleston DB, Lipcius RN, Miller DL, Coba-Cetina L (1990) Shelter scaling regulates survival of juvenile Caribbean spiny lobster Panulirus argus. Mar Ecol. Prog Ser 62:79-88

Einot I, Gabriel KR (1975) A study of the powers of several methods of multiple comparisons. J Am statist Assoc 70: $574-583$

Gaines SD, Roughgarden J (1985) Larval settlement rate: a leading determinant of structure in an ecological community of the marine intertidal zone. Proc natl Acad Sci USA $82: 3707-3711$

Heck KL Jr, Crowder LB (1991) Habitat structure and predator-prey interactions in vegetated aquatic systems. In: Bell SS, McCoy ED, Mushinsky HR (eds) Habitat structure: the physical arrangement of objects in space. Chapman and Hall, New York, p 281-299

Herrnkind WF, Butler MJ, IV (1986) Factors regulating postlarval settlement and juvenile microhabitat use by spiny lobsters Panulirus argus. Mar Ecol Prog Ser 34:23-30

Herrnkind WF, Butler MJ, IV, Tankersley RA (1988) The effects of siltation on recruitment of spiny lobsters, Pan- ulirus argus. Fish Bull US 86:331-338

Hixon MA (1991) Predation as a process structuring coral reef fish populations. In: Sale PF (ed) The ecology of fishes on coral reefs. Academic Press, Inc, New York, p 475-508

Holbrook SJ, Carr MH, Schmitt RJ, Coyer JA (1990) Effect of giant kelp on local abundance of reef fishes: the importance of ontogenetic resource requrements. Bull mar Sci 47:104-114

Jones GP (1984) Population ecology of the temperate reef fish Pseudolabrus celidotus Bloch \& Schneider (Pisces: Labridae). Factors influencing recruitment. J exp mar Biol Ecol $75: 257-276$

Jones GP (1991) Postrecruitment processes in the ecology of coral reef fish populations: a multifactorial perspective. In: Sale PF (ed) The ecology of fishes on coral reefs. Academic Press, Inc, New York, p 294-330

Jory DE, Iversen ES (1989) Species profiles: life histories and environmental requirements of coastal fishes and invertebrates (South Florida), black, red and Nassau groupers. US Fish Wildlife Serv, Biol Rept 82

Kingsford MJ, Choat JH (1986) The influence of surface slicks on the distribution and onshore movement of small fish. Mar Biol 91:161-171

Kingsford MJ, Wolanski E, Choat JH (1991) Influence of tidally induced fronts and Langmuir circulations on distribution and movements of presettlement fishes around a coral reef. Mar Biol 109:167-180

Leis JM (1991) The pelagic stage of reef fishes: the larval biology of coral reef fishes. In: Sale PF (ed) The ecology of fishes on coral reefs. Academic Press, Inc, New York, p $183-230$

Levin PS (1991) Effects of microhabitat on recruitment variation in a Gulf of Maine reef fish. Mar Ecol Prog Ser 75: 183-189

Levin PS (1993) Habitat structure, conspecific presence and spatial variation in the recruitment of a temperate reef fish. Oecologia 94:176-185

Lipcius RN, Hines AH (1986) Varlable functional responses of a marine predator in dissimilar homogeneous microhabitats. Ecology 67:1361-1371

Mackenzie BR, Leggett WC, Peters RH (1990) Estimating larval fish ingestion rates: can laboratory derived values be reliably extrapolated to the wild? Mar Ecol Prog Ser 67 209-225

Marliave JB (1977) Substratum preferences of settling larvae of marine fishes reared in the laboratory. $J$ exp mar Biol Ecol 27:47-60

Marx JM, Herrnkind WF (1985) Macroalgae (Rhodophyta: Laurencia spp.) as habitat for young spiny lobsters, Panulirus argus. Bull mar Sci 36:423-431

McFarland WN (1979) Observations on recruitment in haemulid fishes. Proc Gulf Caribb Fish Inst 32:132-138

McFarland WN, Brothers EB, Ogden JC, Shulman MJ, Bermingham EL, Kotchian-Prentiss NM (1985) Recruitment patterns in young French grunts, Haemulon flavolineatum (family Haemulidae) at St. Croix, U.S.V.I. Fish Bull US 83:413-426

Meekan MG, Milicich MJ, Doherty PJ (1993) Larval production drives temporal patterns of larval supply and recruitment of a coral reef damselfish. Mar Ecol Prog Ser 93: $217-225$

Milicich MJ, Meekan M, Doherty PJ (1992) Larval supply: a good predictor of recruitment of three species of reef fish (Pomacentridae). Mar Ecol Prog Ser 86:153-166

Miller TJ, Crowder LB, Rice JA, Marschall EA (1988) Larval size and recruitment mechanisms in fishes: toward a conceptual framework. Can J Fish Aquat Sci 45:1657-1670 
Moran DP, Reaka ML (1988) Bioerosion and the availability of shelter for benthic reef organisms. Mar Ecol Prog Ser 44: 249-263

Morton RM (1990) Community structure, density and standing crop of fishes in a subtropical Australian mangrove area. Mar Biol 105:385-394

Mullaney MD Jr (1991) Trophic ontogeny, age, growth, and ontogeny of the feeding apparatus in Mycteroperca microlepis (Pisces: Serranidae). MSc thesis, College of Charleston, Charleston, SC

Orth RJ, Heck KL Jr, van Montfrans J (1984) Faunal communities in seagrass beds: a review of the influence of plant structure and prey characteristics on predator-prey relationships. Estuaries 7:339-350

Orth RJ, van Montfrans J (1987) Utilization of a seagrass meadow and tidal marsh creek by blue crabs Callinectes sapidus. I. Seasonal and annual variations in abundance with emphasis on post-settlement juveniles. Mar Ecol Prog Ser 41:283-294

Parrish JD (1989) Fish communities of interacting shallowwater habitats in tropical oceanic regions. Mar Ecol Prog Ser 58:143-160

Pepin P, Pearre S Jr, Koslow JA (1987) Predation on larval fısh by Atlantic mackerel, Scomber scombrus, with a comparison of predation by zooplankton. Can J Fish Aquat Sci 44:2012-2018

Real L (1977) The kunetics of functional response. Am Nat 111:289-300

Real L (1979) Ecological determinants of functional response. Ecology 60:481-485

Robertson DR, Green DG, Victor BC (1988) Temporal coupling of reproduction and recruitment of larvae of a Caribbean reef fish. Ecology 69:370-381

Ross SW, Moser ML (1995) Life history of juvenile gag, MyCteroperca microlepis, in North Carolina estuaries. Bull mar Sci 56:222-237

Russ GR (1991) Coral reef fisheries: effects of yields. In: Sale PF (ed) The ecology of fishes on coral reefs. Academic Press, Inc, New York, p 601-635

Sale PF, Douglas WA, Doherty PJ (1984) Choice of microhabitats by coral reef fishes at settlement. Coral Reefs 3:91-99

Shapiro DY (1987) Inferring larval recruitment strategies from the distributional ecology of settled individuals of a coral reef fish. Bull mar Sci 41:325-343

Shenker JM, Maddox ED, Wishinski E, Pearl A, Thorrold SR, Smith N (1993) Onshore transport of settlement-stage Nassau grouper (Epinephelus striatus) and other fishes in Exuma Sound, Bahamas. Mar Ecol Prog Ser 98:31-43

Shulman MJ (1984) Resource limitation and recruitment patterns in a coral reef fish assemblage. J exp mar Biol Ecol $74: 85-109$

Shulman MJ, Ogden JC (1987) What controls tropical reef fish populations: recruitment or benthic mortality? An exam-

This article was presented by K. L. Heck, Jr (Senıor Editonal Advisor), Dauphin Island, Alabama, USA ple in the Caribbean reef fish Haemulon flavolineatum. Mar Ecol Prog Ser 39:233-242

Smith CL (1972) A spawning aggregation of Nassau grouper. Epinephelus striatus (B.loch). Trans Am Fish Soc 101: $257-261$

Sogard SM, Powell GVN, Holmquist JG (1989) Spatial distribution and trends in abundance of fishes residing in seagrass meadows on Florida Bay mudbanks. Bull mar Sci $44: 179-199$

Steger R (1987) Effects of refuges and recruitment on gonodactylid stomatopods, a guild of mobile prey. Ecology 68:1520-1533

Stoner AW (1983) Distribution of fishes in seagrass meadows role of macrophyte biomass and species composition. Fish Bull US 81:837-846

Sweatman HPA (1985) The influence of adults of some coral reef fishes on larval recruitment. Ecol Monogr 55 $469-485$

Sweatman HPA (1988) Field evidence that settling coral reef fish larvae detect resident fishes using dissolved chemical cues. J exp mar Biol Ecol 124:163-174

Thayer GW, Colby DR, Hettler WF Jr (1987) Utilization of the red mangrove prop root habitat by fishes in south Florida. Mar Ecol Prog Ser 35:25-38

Underwood AJ (1981) Techniques of analysis of variance in experimental marine biology and ecology. Oceanogr mar biol A Rev 19:513-605

Underwood A, Fairweather PG (1989) Supply-side ecology and benthic marine assemblages. Trends Ecol Evol 4 $16-20$

Victor BC (1986) Larval settlement and juvenile mortality in a recruitment-limited coral reef fish population. Ecol Monogr 56:145-160

Victor BC (1991) Settlement strategies and biogeography of reef fishes. In: Sale PF (ed) The ecology of fishes on coral reefs. Academic Press, Inc, New York, p 231-260

Weinstein MP, Heck KL Jr (1979) Ichthyofauna of seagrass meadows along the Caribbean coast of Panama and in the Gulf of Mexico: composition, structure and community ecology. Mar Biol 50:97-107

Werner EE, Gilliam JF (1984) The ontogenetic niche and species interactions in size-structured populations. A Rev Ecol Syst 15:67-93

Williams D McB, Sale PF (1981) Spatial and temporal patterns of recruitment of juvenile coral reef fishes to coral habitats within 'One Tree Lagoon', Great Barrier Reef Mar Biol 65:245-253

Worthington DG, Ferrell. DJ, McNeill SE, Bell JD (1992) Effects of the shoot density of seagrass on fish and decapods: are correlations evident over large spatial scales? Mar Biol 112:139-146

Zar Jf l (1984) Biostatistical analysıs, 2nd edn. Prentice-Hall, Inc, Englewood Cliffs, NJ

Manuscript first received: June 2, 1994

Revised version accepted: March 14, 1995 